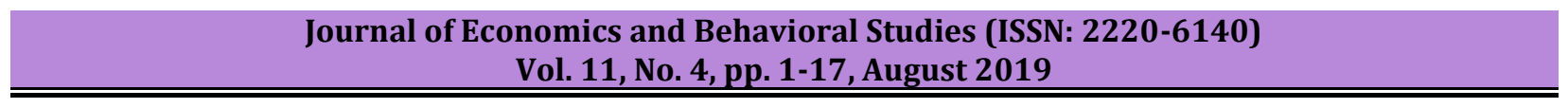

\title{
Human Capital Development and Economic Growth in BRICS Countries: Controlling for Country Differences
}

\author{
Awolusi D. Olawumi \\ Graduate School of Business and Leadership, University of KwaZulu-Natal, South Africa \\ awolusi.olawumi@kiu.ac.ug
}

\begin{abstract}
This paper investigates the effect of human capital development on economic growth, as well as controlling for country differences, in the BRICS economies - from 1990 to 2017. Ordinary Least Square (OLS) and Generalized Method of Moments (GMM) were used as the estimation techniques. We use one-way ANOVA and Scheffe pairwise comparison tests to understand how human capital development differed between each pair of countries. Findings suggest that the effect of human capital development on economic growth, though significant, was limited in these countries. A comparative analysis of results showed that China, Brazil and Russia were able to utilise their human capital to enhance economic growth more efficiently than South Africa and India. Consequently, this study observed that a $1 \%$ increase in government expenditure on education would result in a $0.13 \%$ increase in GDP for China, a $0.06 \%$ increase in Russia, a $0.07 \%$ increase in Brazil, a $0.04 \%$ increase in South Africa, and a $0.01 \%$ increase in GDP in India. In addition, the study concluded that human capital development practices differ in all the countries. Although this result was previously implied in the literature, comparison of a comprehensive list of human capital development practices among countries was lacking. Overall, the paper argues that the classical theory of economic growth, in combination with the new theory, and also the theory of market value, will not only help sustain a strategy tripod, but also shed significant light on the most fundamental questions confronting human capital development and economic growth in many developing economies.
\end{abstract}

\section{Keywords: Human Capital Development, Economic Growth, OLS, GMM, BRICS Economies.}

\section{Introduction}

Human beings are the most important source of growth in productivity and economic growth (Pelinescu, 2015; Ahmad \& Schroeder, 2003; Mankiw, Romer \& Weil, 1992). This is on the premise that equipment and technology are products of human ingenuity. And consequently the success of any productive programme depends on human innovative ideas and creativity (Asikhia and Awolusi, 2015; Mustapha, Fakokunde and Awolusi, 2014; Adelakun, 2011; Pelinescu, 2015). According to Adelakun (2011), human capital can be described as the abilities and skills of human resources. Although sometimes used interchangeably the term 'human capital development', this term refers to the process of acquiring and increasing the number of persons who have the education, skills, and experience which are critical for the economic growth of any nation (Harbison,1962; Adelakun, 2011; Abramowitz, 1981). Corroborating these assertions, the growth theory also emphasises the influence of human capital development on economic growth (Romer, 1986; Lucas, 1988), as the global economy shifts towards more knowledge-based sectors (Adelakun, 2011; Pelinescu, 2015). Today, researchers and practitioners agree that human resources can be a source of competitive advantage that should be managed strategically (Asikhia and Awolusi, 2015; Awolusi, 2013a; Awolusi, 2013b; Ahmad \& Schroeder, 2003; UNCTAD, 2015).

Hence, human capital development is imperative for policy makers in their quest for economic growth and development - both at the national and regional level (RSA, 2013; OECD, 2010). Based on the above background, the BRICS economies have been strategically positioned - not only to increase world growth, but also to serve as a reference model for other developing economies (UNCTAD, 2015; UNDP, 2014). BRIC is a grouping acronym, coined in 2001 by Goldman Sachs analyst Jim O'Neill, and refers to the countries of Brazil, Russia, India and China, which are all deemed to be at a similar stage of newly advanced economic development (Goldman Sachs, 2001). However, after the BRIC countries formed a political organisation among themselves, they later expanded to include South Africa - becoming BRICS (UNDP, 2014). These countries occupy more than $25 \%$ of the habitable surface area of the planet altogether, and $40 \%$ of the world's population live in them (UNCTAD, 2013). China is known as the factory of the world, Brazil as the garden of the world, Russia as the gas station of the world, while the back office of the world is India and 
South Africa is the jeweler of the world and a gateway to Africa (RSA, 2013). The collaboration of these countries is aimed at meeting the economic needs of this Century.

Which include infrastructure development, consumption and increased trade they also have much in common in terms of population, GDP and unemployment? BRICS' collective contribution to world GDP has increased from $11 \%$ in 1990 to $25 \%$ in 2011 . According to Goldman Sachs (2001), these countries are collectively expected to overtake the major economic powers over the next few decades. Their growth is expected to shape a new economic order - replacing the one currently dominated by advanced economies (UNCTAD, 2015; RSA, 2013). However, the BRICS economies are still confronted with numerous problems (e.g. poor investment in road, rail, ports and energy; obsolete capital equipment; very large public debt as a percentage of GDP; environmental issues as obstacles to sustainable growth; increasing income inequality; high unemployment rates; rising labour costs; and a high lending interest rate) that could jeopardise the attainment of these noble objectives (UNCTAD, 2015; UNDP, 2014). Therefore, there is an urgent need to put in place strategies aimed at empowering the citizenry to acquire the required skills and knowledge that would prepare them for the vast challenges ahead (Aregbesola, 2014; Adelakun, 2011). Moreover, various macro-empirical works on the relationship between human capital and economic growth have shown the probable positive impact of human capital development on overall economic growth (Ozturk, 2007). The findings of David Ricardo (comparative advantage), Heckscher-Ohlin (factor proportions), and Porter's Competitive Advantage also establish the inevitability of human capital and other factors as the foundation upon which a nation's economic growth can be built (Aregbesola, 2014; Anyanwu, 2012).

Consequently, the vast literature on human capital development in developing countries clearly indicates the importance of education, improved health facilities, skills, infrastructure, innovation and macroeconomic stability as imperatives for economic growth (Pelinescu, 2015; Ozturk, 2007; Mahe, 2005). While many scholars concur about the positive influence of human capital on economic growth - given government investments and appropriate policies - others also highlight the potential drawbacks (De la Fuente \& Doménech, 2000, 2006; Benhabib \& Spiegel, 1994; Pelinescu, 2015). For instance, De la Fuente and Doménech $(2000,2006)$ observed a positive and significant statistical correlation between production and human capital, both in level and in first-order differences. Ncube (1999) observed an increase of 6\% in GDP per capita given a corresponding increase in duration of schooling by one year in the OECD countries for the period 1971 to 1998. Bundell et al. (1999) also analysed the impact of human capital on economic growth, and established positive relationships between economic growth and the rate of accumulation of human capital and innovation. This is on the premise that higher human capital intensity will permit developing countries to increase their productivity (growth rate) (Aregbesola, 2014; Adelakun, 2011). Consequently, it is imperative for developing economies to maintain a high level of educational attainments via massive investment in human capital (e.g. education, health, law and order, social infrastructures). However, contrary to the above positive sentiments, Benhabib and Spiegel (1994) observed an insignificant effect of human capital on growth of GDP per capita.

Although many of these studies have examined the influence of human capital development on economic growth - with most reporting mixed results - there seem to be only a few empirical analyses on this phenomenon (Pelinescu, 2015; De La Fuente \& Domenéch, 2006; Durham, 2004). In addition, several studies in the literature also investigated the impact of Foreign Direct Investment (FDI) on economic growth (Saggi, 2002; Johnson, 2006; Madsen, 2007; Ozturk, 2007; Durham, 2004; Agrawal \& Khan, 2011), with some of the studies related to improved economic growth. However, they paid little attention to human capital development. This lack of attention is surprising when one considers the critical role of human resources in achieving superior growth and poverty reduction (Pelinescu, 2015; De La Fuente \& Domenéch, 2006). Thus, Pelinescu (2015) specifically suggests the need for a survey of relationships between human capital development and economic growth. In addition, empirical validation of the findings across countries is virtually non-existent and very limited at best (Aregbesola, 2014; Anyanwu, 2012). While recent trends toward globalisation make the study of human capital practices in the context of country a necessity (UNCTAD, 2015; UNDP, 2014; Anyanwu, 2012), the literature has also emphasised the need for generalisability of the relationship between human capital development and economic growth (Ahmad \& Schroeder, 2003; UNCTAD, 2015). Juxtaposing the limited empirical examination of broad-based human capital practices across countries in the literature, Ahmad and Schroeder (2003) observed that previous 
empirical studies which were related to human capital development, have been conducted using data from a single industry within one country; at best.

Some studies used data from multiple industries in one or multiple countries (Pelinescu, 2015; Ahmad \& Schroeder, 2003; Anyanwu, 2012). In addition, unlike previous studies which largely considered either developed and developing economies, or a group of both developed and developing economies, our study focuses solely on developing countries (the BRICS countries)? Hence, the analytical focus was premised on developing countries, due to Wyk and Lal's (2008) submission. According to Wyk and Lal (2008), the practice of pooling developed and developing economies together in analysing the impact of human capital development on growth, is inappropriate. This is because developed economies have substantial amounts of two-way human capital flows - unlike the developing nations (El-Wassal, 2012). The above considered, the main objective of this study was to investigate the effect of human capital development on economic growth as well as controlling for country differences - in the BRICS economies from 1990 to 2017. First, we investigate whether human capital development differs by country. Next, we assess the impact of human capital development on economic growth.

The first step is important, since we intend to identify the generalisable influence of human capital development practices on economic growth across countries, and it is important to understand the differences in human capital development practices in various countries (Pelinescu, 2015; Mustapha et al., Asika and Awolusi, 2013; Awolusi, 2013a; Ahmad \& Schroeder, 2003). By investigating BRICS economies, this study contributes to the existing body of literature on human capital and the economic growth nexus, due to the significant amount of foreign direct investments into these countries during the last few decades. With the abundant natural resources in BRICS and other developing economies, this study also creates an opportunity for strategic improvements in trade, skills, knowledge transfers, and economic growth in these countries (Johnson, 2006; Madsen, 2007). Increased human capital would also stimulate economic growth - thereby enabling the BRICS nations to address some of their persistent problems of high unemployment and poverty (RSA, 2013). Section two of this paper is the literature review; section three details the adopted methodology; section four includes the analysis of the various data collected, and results and discussion of findings; while section five presents the conclusion and implications of the study.

\section{Review of Literature}

Theoretical Framework: A single theoretical perspective could not adequately explain the influence of human capital development on economic growth (Pelinescu, 2015; Mahe, 2005). Consequently, among the most commonly applied theories are classical theory of economic growth and the new theory of economic growth. These two theories are used as the theoretical foundation for almost $70 \%$ of the previous studies on the human capital-growth nexus (Riley, 2012; Lucas, 1988). In addition, the neoclassical models of growth and endogenous growth models also support most of the empirical work on the human capital-growth relationship (Ozturk, 2007; De Mello, 1996, 1999). According to the neoclassical growth theory, economic growth normally comes from strategic accumulation of factors of production and total factor productivity (TFP) growth (Felipe, 1997). That notwithstanding, these two derivatives also depend on the host country's bargaining power in providing the supporting human capital, policies, and infrastructural development (Fedderke \& Romm, 2005). However, the deficiencies noticed in the neoclassical growth theory (difficulties in the measurement of TFP growth and lack of appropriate econometric modeling techniques), gave rise to the endogenous growth theory (Johnson, 2006; Madsen, 2007).

This theory, on the other hand, strengthened the contributions of human capital to the growth debate. The endogenous theory also posits an improvement in economic growth through knowledge transfers and capital formation (Asikhia and Awolusi, 2015; Borensztein et al., 1998; Blomstrom et al., 1996) - but also cautioned on the need to augment the level of knowledge via skill acquisition and labour training (De-Mello, 1997, 1999). Moreover, the importance of technological diffusion and innovation in enhancing economic growth in developing economies was also advanced by other endogenous growth theorists (Asikhia and Awolusi, 2015; Awolusi, 2013b; Eaton \& Kortum, 1999; Young, 1991). Ultimately, the importance of technological change on economic growth is often emphasised in the new growth literature (Grossman \& Helpman, 1990). According to the new growth theory, the growth rate of less developed countries is seen to be greatly dependent on the 
rate at which any developing economy can easily adopt and implement new technologies from developed nations (Ozturk, 2007). However, previous studies (Riley, 2012; De la Fuente \& Doménech, 2000, 2006) indicate that the existing theories do not sufficiently explain.

The influence of human capital development on economic growth, and they have called for either the extension of existing theories or the development of new theories to explain this phenomenon (Mankiw et al., 1992). In addition, much of the existing literature does not agree on the conceptual framework and constructs that should be used to explain the relationships between human capital and economic growth, while a theoretical framework can be based on more than one theory (De la Fuente \& Doménech, 2006). Consequently, the theoretical framework for this study was based on the four (classical theory of economic growth, the new theory of economic growth, the theory of market value, and human capital theory) most common theories of economic growth-human capital nexus (Pistorius, 2004; Siggel, 2000, 2001; Horwitz, 2005). This study was positioned as a step ahead of Funke and Strulik (2000), who adopted a model that incorporates aspects of the classical theory with the new theories of economic growth. However, considering the Grossman-Helpman model and the level of technological growth as an endogenous factor, many studies posit for increased expenditure on research and development to realize the desired economic growth (Pelinescu, 2015; Ahmad \& Schroeder, 2003).

According to Pistorius (2004), the classical theory of economic growth regards labour productivity as an exogenous factor, which often fails to reflect the beneficial influence of education on the potential growth of productivity. This shortcoming was corrected by the new theory of economic growth, with emphasis on the influence of education and innovation on long-term economic growth (Riley, 2012). This is on the premise that - as physical capital contributes to improvements in income per capita in the early stages of development - the accumulation of knowledge (through continuing education and training) ultimately leads to higher stages of development (Ahmad \& Schroeder, 2003). These investments are usually in the form of government expenditure on education, health, infrastructure, nutrition and social protection (Asikhia and Awolusi, 2015; Awolusi, 2013a; Siggel, 2001; Horwitz, 2005). Adelakun (2011) also maintains that government provision of education is seen as being a productive investment in human capital development, an investment which is sometimes preferred to physical capital acquisition. This assertion is also corroborated by the modernisation theory, with a focus on the transformational capabilities of education and institutions (such as schools, factories, and mass media) on individual's beliefs, values, and behavior (Aregbesola, 2014).

According to this theory, the greater the number of people exposed to modernisation institutions, the greater the level of economic growth and development (Adelakun, 2011). However, differing to the above theories, the theory of market value extended these imperatives to intangible assets such as patents and intellectual capital, and research and development (De la Fuente \& Doménech, 2000, 2006). The human capital theory views education and training as an investment in skills and competences (Schultz, 1992). According to Aregbesola (2014), individuals make decisions on the education and training they receive in order to improve their productivity. Consequently, the human capital theory posits that a more educated or skilled workforce makes it easier for an organisation to adopt and implement new technologies and innovative capabilities (Adelakun, 2011). In addition to recognising employee experience, skills, and knowledge as assets with the potential to generate economic rent; the human capital theory evaluates human resources through productivity gains (Ahmad \& Schroeder, 2003).Ahmad and Schroeder (2003), while drawing on a behavioural psychology-perspective, highlighted the strategic aspect of human capital practices and argued why these practices can lead to competitive advantage in many developing nations. Consequently, the four human capital indices suggested by Pelinescu (2015) are expected to foster such inimitable attributes in human capital development and thereby help developing countries attain a competitive advantage.

Human Capital Development and Economic Growth: Human capital is an important factor in the production process (Pelinescu, 2015; Ahmad \& Schroeder, 2003). Consequently, the development and utilisation of human capital is important in a nation's quest for economic growth and poverty reduction (Adelakun, 2011). On the other hand, GDP (proxy for economic growth) indicates the amount of economic production taking place in an economy, calculated as the total output within a specific year (Pelinescu, 2015). A number of interesting studies on the role of FDI in stimulating economic growth have appeared in the past three decades. Notable are the broad methodological series, starting from the Solow structural econometric 
models, to the convergence analyses proposed by Barro and Sala i Martin (1995) - through to the panel models in cross-country data analysis (Islam, 1995; Pelinescu, 2015). That notwithstanding, Bhagwati (1978) was the first to present a theory on the influence of FDI and human capital on growth in a given host country. An extension of the theory (popularly referred to as "Bhagwati hypothesis") highlighted the role of cheap human capital (labour) as a catalyst to increased competitive and export-oriented products in a relatively free environment (Bhagwati, 1985, 1994; Brecher \& Findlay, 1983). In addition, economic growth can also be accelerated via employment, and through sharing of knowledge and management skills' integration in the host country (Frenkel et al., 2004). Government investment in innovation, R\&D, and learning, may also generate productivity spillovers for the host economy (Temple, 1999; Blomstrom \& Kokko, 1998). As an extension to the literature on FDI, the impact of human capital development practices on economic growth has also been the subject of much attention over the years. A large body of literature has revealed the influence of human capital on economic growth (Riley, 2012; Lucas, 1988; Mankiw et al., 1992; De la Fuente \& Doménech, 2000, 2006; Serena \& Freire, 2001) - with regard to both the effect of level (so called level effect).

Its decisive influence on production through labor productivity (Romer, 1990; Mankiw, Romer \& Weil, 1992) and the rate effect by contributing to increased competitive advantage through innovation and diffusion of technology (Pistorius, 200; Siggel, 2000, 2001; Horwitz, 2005). For instance, the positive influence of quality education more than quantity was highlighted by Hanushek and Kimko (2000) and Hanushek and Woessmann (2007) in these studies, human capital development was proxied by the results of PISA and TIMS tests. Similarly, Hanushek and Schultz (2012) showed that a 100 point divergence in PISA test results would lead to a $2 \%$ difference in the growth rate of GDP per capita (Pelinescu, 2015; Okojie, 1995). Other studies also show the positive influence of human capital development on economic growth (Odusola, 1998; Barro \& Sala-i-Martin, 1995). However, in a deviation from previous studies, Filmer and Pritchett (2001) specifically show lack of significant relationships between improved human capital via higher educational attainments and the rate of growth of output per worker.

Control Variable: Part of the objectives of this study was the need to identify the influences of human capital development practices on economic growth that can be generalized across countries, but the effects of the country need to be ascertained prior to evaluating the relationships (Ahmad \& Schroeder, 2003; Anyanwu, 2011, 2012). This study therefore included the following country control variables in the regression analyses: Russia (Russia compared to China), Brazil (Brazil compared to China), South Africa (South Africa compared to China) and India (India compared to China), are used to represent the five countries. This is on the premise that studies have argued that human capital development practices can differ across countries for several reasons (e.g. cultural idiosyncrasy, governmental regulations and policies, competitive priorities), and its adoption for both managerial and theoretical practices (Pelinescu, 2015; Ahmad \& Schroeder, 2003; Aregbesola, 2014; Anyanwu, 2012; Gustav \& Stewart, 2001). These studies also juxtaposed previous emphasis on the generalisability of the relationship between human capital development and economic growth.

For example, Pelinescu (2015) and Ahmad and Schroeder (2003) raise concerns that the results of previous studies on human capital practices and economic growth may not be valid in other countries. These studies urged and advised the need to validate and some of these studies in other countries in order to rule out country effects. Consequently, the impact of human capital development on economic growth in the BRICS economies can be generalised across many developing countries, if we find support for the set of hypotheses below: H1. After controlling for the country effects, economic growth will be positively related to each of the following seven human capital practices:(a) government expenditure on education;(b) government expenditure on health; (c) weighted average of the population registered in primary, secondary and tertiary education; (d) number of employees with secondary education; (e) exports of goods and services; (f) registered patents and intellectual capital, and (g) expenditure on research and development.

\section{Methodology}

Given that the economic model specification is based on economic theory and on the available data relating to the human capital being studied (Mankiw et al., 1992), the study employed a modified model from the works of Pelinescu (2015), Adelakun (2011), and Mankiw et al. (1992). Based on the availability of data, the time- 
series data (annual data, stationary by logarithm) of the BRICS countries (Brazil, Russia, India, China, and South Africa) from 1990 to 2017, were estimated using Ordinary Least Squares regression (OLS) and the Generalised Method of Moments (GMM). Firstly, to control for country differences, we use one-way ANOVA and Schaffer pairwise comparison tests to understand how human capital management differed between each pair of countries. Secondly, we performed an OLS with time fixed effects. In addition, due to a probable endogeneity and serial correlation of the error term (Coe \& Helpman, 1995; Keller, 2002), the second stage was complemented with the GMM technique to provide consistent estimates (Keller, 2001). The data set was collected from the following sources: United Nations Conference on Trade and Development, United Nations Development Programme Database, World Bank Databank, World Economic Forum database, the International Monetary Fund (IMF), the United Nations Statistics Database (UN data), and publications of national central banks and other agencies of the governments of the BRICS countries.

OLS and GMM Estimation Techniques: The source model for this study was based on the work of Pelinescu (2015), Adelakun (2011), and Mankiw et al. (1992)-as stated in equation 1.

In RGDPGRt $=\alpha 0+\alpha 1$, In It $+\alpha 2$ InEMPt $+\alpha 3$ InHt + ut .equation 1

Given $\alpha 1, \alpha 2, \alpha 3>0$, RGDPGR is the growth rate of real gross domestic product, I is investment to GDP ratio, EMP is employment rate, $\mathrm{H}$ is human capital proxied by total capital expenditure on health and education, and In stands for logarithm transformation. However, it is important to note that the source model was constructed from the basic production function below:

$\mathrm{Y}=\mathrm{f}(\mathrm{K}, \mathrm{L})$..... .equation 2

Where:

Y= Output level (i.e. GDP),

$\mathrm{K}=$ Capital (Gross Capital Formation (GCF) as percentage of GDP), and

$\mathrm{L}=$ Labour (Country's labour force).

Equation 2 is based on the assumption that $\mathrm{K}$ and $\mathrm{L}$ determine the level of output in an economy (Ogutcu, 2002). Consequently, given constant technology, an increase in labour and/or capital will increase output level in the economy. However, based on the new growth theory (Barro \& Sala-i-Martin, 1995; Ogutcu, 2002), to analyze the effect of human capital on economic growth, the Coub-Douglas Production Function (equation 2) was expanded with the addition of human capital $(\mathrm{H})$. Consequently, the augmented production function can be stated thus:

$\mathrm{Y}=\mathrm{f}(\mathrm{K}, \mathrm{L}, \mathrm{H})$ equation 3.

Alternatively, equation 3 can be stated thus:

$\log ($ GDP_PPP $)=\alpha \log H+\beta \log X+\theta i+\gamma t+\varepsilon$ equation 4

In the abridged equation 4, the dependent variable is the logarithm of real per capita GDP (GDP_PPP), and is a direct function of human capital $(\mathrm{H})$ and other relevant factors $(\mathrm{X}) \cdot \gamma \mathrm{t}$ and $\theta \mathrm{i}$ are dummy variables capturing the time and country fixed effects, and $\varepsilon$ is the error term. In summary, given the small sample (selected BRICS countries) size, the assumptions of the GMM dynamic estimator also applies:

$s=2$ and $t=3, \ldots, T$,

$E\left[Y_{i, t-s} .\left(\varepsilon_{i, t}-\varepsilon_{i, t-1}\right)\right]=0$, where $s \geq 2 ; t=3, \ldots, T$, .equation 5

$E\left[Z_{i, t-s .} .\left(\varepsilon_{i, t}-\varepsilon_{i, t-1}\right)\right]=0$, where $s \geq 2 ; t=3, \ldots, T$ equation 6

Therefore equation 4 can be translated and expanded to our multiple regression equation:

$\mathrm{Y}_{\mathrm{i}, \mathrm{t}}=\beta_{0}+\beta_{1} \mathrm{GEE}_{\mathrm{i}, \mathrm{t}}+\beta_{2} \mathrm{GEH}_{\mathrm{i}, \mathrm{t}}+\beta_{3} \mathrm{PPST}_{\mathrm{i}, \mathrm{t}}+\beta_{4} \mathrm{ESE}_{\mathrm{i}, \mathrm{t}}+\beta_{5} \mathrm{EXP}_{\mathrm{i}, \mathrm{t}}+\beta_{6} \mathrm{P} \& \mathrm{I}, \mathrm{i}+\beta_{7} \mathrm{R}_{\mathrm{a}} \mathrm{D}_{\mathrm{i}, \mathrm{t}}+\mu_{\mathrm{i}}+\varepsilon_{\mathrm{i}, \mathrm{t}} \ldots \ldots \ldots . .$. equation 7.

Where $Y=$ real per capita GDP (GDP_PPP),

GEE $=$ Total government expenditure on education

$\mathrm{GEH}=$ Total government expenditure on health

PPST $=$ Weighted average of the population registered in primary, secondary and tertiary Education,

ESE $=$ Number of employees with secondary education

EXP $=$ Exports of goods and services

$\mathrm{P} \& \mathrm{I}=$ No of registered patents and intellectual capital

$\mathrm{R} \& \mathrm{D}=$ Expenditure on research and development

$\beta_{0}=$ Total Factor Productivity 
$\mu_{\mathrm{i}}=$ country specific effects, and

$\varepsilon_{\mathrm{i}, \mathrm{t}}=$ the error term.

Surprisingly, government attention to the health sector was highest in South Africa and lowest in Brazil. Another surprising result was the attitude of government expenditure and management of research and development, and patent and intellectual capital, despite huge government expenditure on education in Russia. This seems to support Awan (2013), who found that Russia, which was endowed with human capital right from the beginning, has not been able to utilise her human capital potential during the transitional period from planned economy to market economy since the 1990s. In summary, this study found that human capital practices vary widely by country. The differences may not be unconnected with the level of natural resources, national culture, location variables, and institutional capabilities (Pelinescu, 2015; Awan, 2013).

Operationalisation of the Dependent and Explanatory Variables: A stochastic element $\varepsilon$ and $\beta$ are parameter to be estimated. GDP (PPP) is measured using the World Bank's Purchasing Power Parity (PPP) levels. GDP at PPP uses exchange rates to benchmark the sum value of all goods and services produced in a country valued at prices prevailing in US\$. This makes possible comparisons amongst different countries (Pelinescu, 2015; Adelakun, 2011; Grammy \& Assane, 1996). Measurement of human capital development was based on the human capital index, which in determination of the European Union, is based on four groups of areas (investment in education, the use of human capital stock, the productivity of human capital, and employment of human capital). This is similar to the human capital index determined by the World Economic Forum (includes 4 pillars: Education, Wealth and Wellness, Workforce, and Employment and Enabling Environment- which includes infrastructure, legal and other factors that ensure valuing of human capital). All the constructs and their measures are shown in Table 1 (below). However, log values of the variables were used to facilitate the use of the ordinary least square method (Agrawal \& Khan, 2011; Bils \& Klenow, 2000).

Table 1: The Measure of Constructs (Dependent and Explanatory Variable)

\begin{tabular}{|c|c|c|c|}
\hline Variable & Measure & Theory & Author \\
\hline GDP_PPP & Real level of GDP per capita & & $\begin{array}{l}\text { Riley, 201; Lucas, 1988; Mankiw et } \\
\text { al. 1992; Pelinescu, } 2015\end{array}$ \\
\hline GEE & $\begin{array}{l}\text { Total government expenditure on } \\
\text { education }\end{array}$ & Classical & $\begin{array}{l}\text { De la Fuente and Doménech, } \\
\text { 2000, 2006; Pelinescu, } 2015\end{array}$ \\
\hline GEH & $\begin{array}{l}\text { Total government expenditure on } \\
\text { health }\end{array}$ & Classical & $\begin{array}{l}\text { De la Fuente and Doménech, 2000, } \\
\text { 2006; Pelinescu, } 2015\end{array}$ \\
\hline PPST & $\begin{array}{l}\text { Weighted average of the population } \\
\text { registered in primary, secondary and } \\
\text { tertiary education }\end{array}$ & New theory & Murthy and Chien, 1997 \\
\hline ESE & $\begin{array}{l}\text { Number of employees with secondary } \\
\text { education }\end{array}$ & $\begin{array}{l}\text { Classical/New } \\
\text { theory }\end{array}$ & $\begin{array}{l}\text { Mankiw, Romer and Weil, 1992; } \\
\text { Pelinescu, } 2015\end{array}$ \\
\hline EXP & Exports of goods and services & Market value & Romer, 1990;Pelinescu, 2015 \\
\hline P\&I & $\begin{array}{l}\text { No of registered patents and } \\
\text { intellectual capital }\end{array}$ & Market value & Pistorius, 2004; Siggel, 2000, 2001 \\
\hline $\mathrm{R} \& \mathrm{D}$ & $\begin{array}{lll}\begin{array}{l}\text { Expenditure } \\
\text { development }\end{array} & & \text { research } \\
\end{array}$ & Market value & $\begin{array}{l}\text { Pistorius, 2004; Siggel, 2000, } \\
\text { 2001; Horwitz, 2005 }\end{array}$ \\
\hline
\end{tabular}

\section{Results and Discussion of Findings}

We here first present the unit root test results. Second, we conduct a statistical analysis to determine the extent to which human capital development practices differ across countries. Third, the estimated regression results are presented to test the hypotheses. Lastly, the discussion of findings is presented based on the hypotheses stated earlier.

Unit Root Test: A standard augmented Dickey-Fuller (ADF) test and Phillips Perron (PP) test was conducted to test for non-stationarity (presence of unit roots), to eliminate autocorrelation, and whiten noise and 
uncorrelated error terms (Hair et al., 1998). These tests were conducted at level, first difference and second difference series (Hair et al., 1998; Ozturk, 2007). The results of the unit root tests are presented in Table 2 (below).

Table 2: Summary of Unit Root Test Results

\begin{tabular}{|c|c|c|c|}
\hline Variables & ADF Test: $2^{\text {nd }}$ Diff. Statistics & PP Test: $2^{\text {nd }}$ Diff. Statistics & Order of Integration \\
\hline \multicolumn{4}{|l|}{ China } \\
\hline Ln GEE & -5.467644 & -3.765446 & $1(2)$ \\
\hline Ln GEH & -7.345327 & -5.765237 & $1(2)$ \\
\hline Ln PPST & -5.754635 & -3.697335 & $1(2)$ \\
\hline Ln ESE & -3.763453 & -4.573655 & $1(2)$ \\
\hline Ln EXP & -2.675434 & -3.662856 & $1(2)$ \\
\hline Ln P\&I & -3.243677 & -3.345335 & $1(2)$ \\
\hline Ln R\&D & -4.355767 & -5.356754 & $1(2)$ \\
\hline \multicolumn{4}{|l|}{ RUSSIA } \\
\hline Ln GEE & -5.375645 & -3.945567 & $1(2)$ \\
\hline Ln GEH & -4.456567 & -4.945567 & $1(2)$ \\
\hline Ln PPST & -2.445456 & -6.793456 & $1(2)$ \\
\hline Ln ESE & -3.455673 & -4.565554 & $1(2)$ \\
\hline Ln EXP & -3.546354 & -5.193452 & $1(2)$ \\
\hline Ln P\&I & -4.566644 & -3.234566 & $1(2)$ \\
\hline Ln R\&D & -4.675744 & -5.356754 & $1(2)$ \\
\hline \multicolumn{4}{|l|}{ BRAZIL } \\
\hline Ln GEE & -5.865475 & -3.334556 & $1(2)$ \\
\hline Ln GEH & -4.735495 & -5.334526 & $1(2)$ \\
\hline Ln PPST & -3.554456 & -1.456745 & $1(2)$ \\
\hline Ln ESE & -4.767556 & -6.745637 & $1(2)$ \\
\hline Ln EXP & -3.564667 & -3.352567 & $1(2)$ \\
\hline Ln P\&I & -4.456357 & -5.733453 & $1(2)$ \\
\hline Ln R\&D & -2.566654 & -3.356754 & $1(2)$ \\
\hline \multicolumn{4}{|c|}{ SOUTH AFRICA } \\
\hline Ln GEE & -3.655725 & -3.845557 & $1(2)$ \\
\hline Ln GEH & -3.655657 & -3.845637 & $1(2)$ \\
\hline Ln PPST & -4.777678 & -4.848579 & $1(2)$ \\
\hline Ln ESE & -3.754567 & -2.774538 & $1(2)$ \\
\hline Ln EXP & -3.767754 & -4.845683 & $1(2)$ \\
\hline Ln P\&I & -3.455432 & -5.467545 & $1(2)$ \\
\hline Ln R\&D & -4.653555 & -4.356754 & $1(2)$ \\
\hline \multicolumn{4}{|l|}{ INDIA } \\
\hline Ln GEE & -3.455676 & -5.345637 & $1(2)$ \\
\hline Ln GEH & -4.564656 & -4.345637 & $1(2)$ \\
\hline Ln PPST & -3.554678 & -3.898547 & $1(2)$ \\
\hline Ln ESE & -4.985686 & -3.234256 & $1(2)$ \\
\hline Ln EXP & -3.786877 & -4.239657 & $1(2)$ \\
\hline Ln P\&I & -5.755464 & -2.395557 & $1(2)$ \\
\hline Ln R\&D & -3.655465 & -5.356754 & $1(2)$ \\
\hline
\end{tabular}

Note: Critical Values: (ADF): 1\% -3.45639; 5\% -2.98834; 10\% -2.3444; (Phillips-Perron): 1\% -3.3435; 5\% $2.74564 ; 10 \%-2.27782$. The results of the unit root test simply assumed stationarity of the series for all the variables (by rejecting the null hypothesis for second difference at all the critical values). Therefore, the models follow an integrating order of 1(2) process and are a stationary process (Ozturk, 2007). 
One-Way Anova and Scheffe Pairwise Comparison Tests Result: One of the main strategic intents of this study was to identify generalisable impacts of human capital development practices on economic growth across countries. The study used one-way ANOVA to identify differences in human capital development practices among the five BRICS countries. The output of this test is shown in table 3 (below). From Table $3, F$ statistics for all the human capital development practices were found to be highly significant. This simply implied differential in the mean efforts expended in all the human capital development practices in all the BRICS countries. It could be concluded that human capital development practices differ in all the countries, due to the statistical significance of the F-statistics (Ahmad \& Schroeder, 2003). The variations may be because human capital development is a set of interrelated and internally consistent human capital practices that are expected to create mutually reinforcing and synergistic impacts on economic growth (Adelakun, 2011; Ahmad \& Schroeder, 2003). Although this result was previously implied in the literature (Pelinescu, 2015; Ahmad \& Schroeder, 2003), comparison of a comprehensive list of human capital development practices among countries was lacking. This is a unique finding of this study, since it empirically validates ideal-type human capital development in many developing countries.

Table 3: Human Capital Development Practices across Countries

\begin{tabular}{|c|c|c|c|c|c|c|c|c|}
\hline \multirow{2}{*}{$\begin{array}{l}\text { Human } \\
\text { Capital } \\
\text { Practice }\end{array}$} & \multicolumn{5}{|c|}{ Countries } & \multirow[t]{2}{*}{ Pairwise differences } & \multirow{2}{*}{$\begin{array}{l}F \text { - } \\
\text { value }\end{array}$} & \multirow[t]{2}{*}{ Significance } \\
\hline & $\begin{array}{l}\text { RUSSIA } \\
\text { (1) }\end{array}$ & $\begin{array}{l}\text { BRAZIL } \\
\text { (2) }\end{array}$ & $\begin{array}{l}\text { SOUTH } \\
\text { AFRICA } \\
\text { (3) }\end{array}$ & $\begin{array}{l}\text { INDIA } \\
\text { (4) }\end{array}$ & $\begin{array}{l}\text { CHINA } \\
\text { (5) }\end{array}$ & & & \\
\hline GEE & 7.20 & 7.56 & 5.87 & 5.67 & 12.42 & 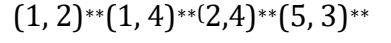 & 6.29 & 0.01 \\
\hline GEH & 6.33 & 2.34 & 9.21 & 3.29 & 8.76 & $(1,2)^{* *}(1,3)^{* *}(3,4)^{* *}(5,3)^{* *}$ & 12.28 & 0.01 \\
\hline PPST & 23.43 & 6.31 & 5.12 & 6.01 & 18.21 & $(1,3)^{* *}(3,1)^{* *}(3,4)^{* *}(4,5)^{* *}$ & 18.08 & 0.01 \\
\hline ESE & 20.41 & 13.38 & 4.38 & 5.38 & 17.38 & $(1,2)^{* *}(1,4)^{* *}(3,2)^{* *}(4,2)^{*}$ & 7.24 & 0.00 \\
\hline EXP & 23.32 & 13.11 & 3.11 & 4.15 & 33.11 & $(1,2) *(3,4) * *(4,2) *$ & 11.27 & 0.00 \\
\hline P\&I & 3.44 & 8.34 & 6.58 & 6.56 & 13.37 & $(1,2) *(3,2) * *(3,5) * *$ & 6.36 & 0.01 \\
\hline$R \& D$ & 4.12 & 7.33 & 6.15 & 5.33 & 8.65 & $(1,4)^{* *}(2,3)^{* *}(3,2) *(4,2) *$ & 12.46 & 0.00 \\
\hline
\end{tabular}

Note: ${ }^{*}, * *, * *$ denote significance at $1 \%, 5 \%, 10 \%$ levels.

Additionally, to control for country differences, the Scheffe pairwise comparison tests of mean differences were conducted to better understand how human capital practices differed between each pair of countries (Pelinescu, 2015; Ahmad \& Schroeder, 2003). Based on the output in Table 3, the comparison revealed several key aspects of human capital development practices, as they are used in different countries. Compared to other countries in this sample, South Africa and India seem to be significantly lacking in their efforts in several human capital development practices. Although South Africa performed better in the health sector, the country recorded the least effort on variables like GEE, PPST, and ESE. India also performed poorly on variables like GEH, P\&I, and R\&D, when compared with South Africa. Moreover, government expenditure on education was given highest priority in China and the lowest in South Africa. In addition, China performed better than other countries on variables like GEH, EXP, P\&I and R\&D.

OLS and GMM Results and Discussion of Findings: In all the human capital development measures, the assumption of independent errors was tested with the Durbin-Watson statistics, which monitor for serial correlations between errors (Akinlo, 2004). Estimated values of 1.99, 2.03, 1.98, 2.03, and 2.10 for China, Russia, Brazil, South Africa, and India respectively, complies with the assumption of no independent errors (Coe \& Helpman, 1995). 


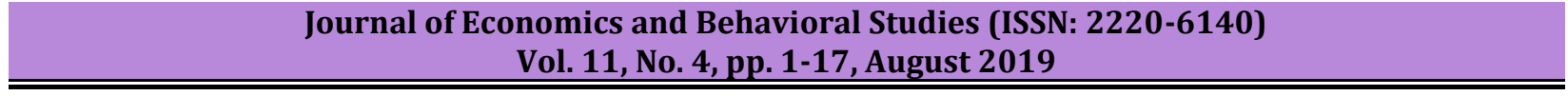

Table 4: OLS and GMM Estimation Regression Results for Human Capital Development

\begin{tabular}{|c|c|c|c|c|c|c|}
\hline \multirow[b]{2}{*}{ CHINA } & \multirow[b]{2}{*}{ Variable } & \multicolumn{2}{|l|}{ OLS } & \multicolumn{3}{|l|}{ GMM } \\
\hline & & $\beta$-Coefficient & t-Statistic & $\beta$-coefficient & t-Statistic & Probability \\
\hline & GEE & $0.13^{* *}$ & 3.67 & $0.22^{*}$ & 3.76 & 0.07 \\
\hline & GEH & $0.13^{* *}$ & 3.17 & $0.21^{* *}$ & 4.98 & 0.08 \\
\hline & PPST & $7.56^{*}$ & 7.30 & $8.45^{* *}$ & 7.44 & 0.05 \\
\hline & ESE & $6.53^{* *}$ & 9.19 & $3.34^{* * *}$ & 2.75 & 0.00 \\
\hline & EXP & $15.33^{*}$ & 8.33 & $16.11^{*}$ & 2.39 & 0.00 \\
\hline & P\&I & $9.34^{*}$ & 9.78 & $7.23^{*}$ & 4.67 & 0.09 \\
\hline & $\mathrm{R} \& \mathrm{D}$ & $7.34^{*}$ & 9.42 & $4.33^{*}$ & 3.62 & 0.06 \\
\hline & Constant & $144.61^{*}$ & 23.11 & \multirow{2}{*}{\multicolumn{2}{|c|}{ Durbin-Watson $=1.99$}} & 0.00 \\
\hline & & $\mathrm{R}^{2}=0.69$ & Adjusted R2 =0.61 & & & \\
\hline \multirow[t]{10}{*}{ RUSSIA } & Variable & \multicolumn{2}{|l|}{ OLS } & \multicolumn{3}{|c|}{ GMM } \\
\hline & & $\beta$-Coefficient & t-Statistic & $\beta$-Coefficient & t-Statistic & Probability \\
\hline & GEE & $0.06^{* *}$ & 1.33 & 0.02 & 4.91 & 0.03 \\
\hline & GEH & $0.09 *$ & 3.34 & $1.66^{* *}$ & 3.97 & 0.07 \\
\hline & PPST & $9.21^{* *}$ & 6.51 & $9.94^{* *}$ & 3.87 & 0.00 \\
\hline & ESE & $14.38^{* *}$ & 6.51 & $13.04^{* *}$ & 2.98 & 0.00 \\
\hline & EXP & $5.19 *$ & 4.24 & $4.15^{* *}$ & 4.39 & 0.00 \\
\hline & P\&I & $5.85^{* *}$ & 5.34 & -4.26 & 2.64 & 0.01 \\
\hline & $\mathrm{R} \& \mathrm{D}$ & $-1.35^{* *}$ & 7.31 & $2.21^{* * *}$ & 3.22 & 0.06 \\
\hline & Constant & $113.29 * *$ & 22.81 & $129.29 * *$ & 19.20 & 0.02 \\
\hline BRAZIL & Variable & $\begin{array}{l}\mathrm{r}=0.56 \quad \mathrm{R}^{2}=0.57 \\
\mathrm{OLS}\end{array}$ & Adjusted $\mathrm{R}^{2}=0.51$ & $\begin{array}{l}\text { Durbin-Watso } \\
\text { GMM }\end{array}$ & 2.03 & \\
\hline & & $\beta$-Coefficient & t-Statistic & $\beta$-Coefficient & t-Statistic & Probability \\
\hline & GEE & $0.07^{* *}$ & 4.63 & $0.10^{*}$ & 3.98 & 0.09 \\
\hline & GEH & $0.05^{* *}$ & 3.63 & $0.06^{* *}$ & 7.99 & 0.00 \\
\hline & PPST & $5.43^{* * *}$ & 10.51 & $8.34^{* * *}$ & 3.28 & 0.03 \\
\hline & ESE & $6.76^{* * *}$ & 9.66 & $5.56^{* *}$ & 2.77 & 0.01 \\
\hline & EXP & $11.61^{* * *}$ & 7.39 & $-4.11^{* *}$ & -2.31 & 0.00 \\
\hline & P\&I & $12.76^{* * *}$ & 5.06 & $5.26^{* *}$ & 1.69 & 0.00 \\
\hline & $\mathrm{R} \& \mathrm{D}$ & $9.73^{* * *}$ & 6.01 & $7.23^{* *}$ & 2.34 & 0.06 \\
\hline & Constant & $83.42^{* * *}$ & 15.42 & $42.21^{* * *}$ & 20.72 & 0.00 \\
\hline & & $\mathrm{r}=0.51 \quad \mathrm{R}^{2}=0.71$ & Adjusted R² =0.66 & Durbin-Watso & 1.98 & \\
\hline SOUTH & Variable & OLS & & GMM & & \\
\hline AFRICA & & $\beta$-Coefficient & t-Statistic & $\beta$-Coefficient & t-Statistic & Probability \\
\hline & GEE & $0.04^{* *}$ & 1.33 & $0.04^{* * *}$ & 2.44 & 0.08 \\
\hline & GEH & $0.10^{* * *}$ & 3.45 & $0.12^{*}$ & 3.91 & 0.07 \\
\hline & PPST & $3.33^{* * *}$ & 3.18 & $4.98^{* *}$ & 3.19 & 0.10 \\
\hline & ESE & $5.44^{* * *}$ & 4.38 & $5.94^{* * *}$ & 5.94 & 0.00 \\
\hline & EXP & $5.66^{* *}$ & 4.34 & $3.11^{* * *}$ & 2.31 & 0.00 \\
\hline & P\&I & $6.32^{* *}$ & 4.88 & $5.23^{* * *}$ & 1.63 & 0.01 \\
\hline & $\mathrm{R} \& \mathrm{D}$ & $5.62^{* *}$ & 5.11 & $4.21^{*}$ & 3.64 & 0.03 \\
\hline & Constant & $91.33^{* * *}$ & 23.33 & $55.44^{* *}$ & 18.31 & 0.00 \\
\hline & & $r=0.45$ & 6 Adjusted $\mathrm{R}^{2}=0.49$ & Durbin-Watso & 2.03 & \\
\hline INDIA & Variable & OLS & & GMM & & \\
\hline & & $\beta$-Coefficient & t-Statistic & $\beta$-Coefficient & t-Statistic & Probability \\
\hline & GEE & 0.01 & 1.32 & $0.05^{* * *}$ & 0.21 & 0.00 \\
\hline & GEH & $0.06^{* *}$ & 4.31 & $2.11^{* *}$ & 3.25 & 0.08 \\
\hline & PPST & -1.32 & -0.13 & -3.55 & -5.28 & 0.00 \\
\hline & ESE & $2.44^{* * *}$ & 5.37 & $2.34^{* * *}$ & 1.22 & 0.04 \\
\hline & EXP & $-3.62^{* *}$ & 4.76 & $3.11 * *$ & -2.44 & 0.07 \\
\hline & P\&I & $4.39 * *$ & 2.77 & $4.23 * * *$ & -1.66 & 0.09 \\
\hline & $\mathrm{R} \& \mathrm{D}$ & $2.33^{* *}$ & 2.77 & $-4.23 * *$ & -1.66 & 0.10 \\
\hline & Constant & $91.22^{* * *}$ & 14.99 & $105.21^{* *}$ & 19.21 & 0.00 \\
\hline & & $\mathrm{R}^{2}=0.35$ & Adjusted $\mathrm{R}^{2}=0.29$ & Durbin-Watson = & & \\
\hline
\end{tabular}

Note: $*, * *, * * *$ denote significance at $1 \%, 5 \%, 10 \%$ levels. 
It also shows the absence of autocorrelation (Keller, 2001, 2002). The OLS and GMM estimation regression results for all the BRICS countries are shown in table 4 (below). Human capital development has played a vital role in the fast economic growth of the BRICS countries - especially China, Russia and Brazil. All the results have significant relationships with economic growth at varying levels except the influence of total government expenditure on education and the proportion of the population registered in primary, secondary and tertiary education in India. In general, the impact of human capital development on economic growth in BRICS countries is limited, and in some cases negligible for both OLS and GMM estimators. In the model of China, all the human capital development variables were positive and significant for both OLS and GMM, at varying levels of significance. In fact, China had the best results among the BRICS countries during the study period. The correlation coefficient ( $\mathrm{r}$ ) at 0.62 denotes a positive relationship between economic growth and human capital development. The adjusted $\mathrm{R}^{2}$ at 0.61 implies that about $61 \%$ variations in economic growth can be explained by human capital development practices, while the remaining $39 \%$ were due to other variables outside the regression model.

Although China recorded the best results in our study, the estimate of human capital development variables was limited, especially GEE and GEH, for both OLS and GMM. This indicates that human capital development contributed minimally in explaining the level of economic growth in China during the study period. For instance, a coefficient of 0.13 implies that a $1 \%$ increase in total government expenditure on education would result in a $0.13 \%$ increase in GDP for China. Russia also recorded minimal results in our study. Although the correlation coefficient (r) at 0.56 also implied a positive relationship between economic growth and human capital development, while the adjusted $\mathrm{R}^{2}$ of 0.51 implied explanation for about $51 \%$ variations in economic growth, the estimate of human capital variables was also limited (especially GEE and GEH) for both OLS and GMM estimators. Specifically, the coefficient of 0.06 for government expenditure on education implies that a $1 \%$ increase in total government expenditure on education would result in a $0.06 \%$ increase in GDP for Russia. In fact, the influence later reduced to 0.02 over the years, judging by the result of the GMM estimator. Another surprising result was the inability of Russia to improve the contribution of R\&D and P\&I to economic growth - despite the country's human capital endowments right from the beginning through its transitional period from planned economy to market economy since the 1990 s.

According to Awan (2013), this was attributed to policy failure to capitalise on the value of human capital in accelerating economic growth. This also resulted in the scaling down of the Russian Federation to a middle income economy. Corroborating this stance, Agrawal and Khan (2011) also observed that government policies and programmes should always take cognisance of the expectations for sustained economic and population growth, by constantly comparing the quality of education and training needs of its citizens (Hailu, 2010; UNESCO, 2005). The estimated result for Brazil was relatively better than the results for Russia, South Africa and India. The human capital estimates were all positive and significant at varying levels for OLS and GMM. This was also corroborated with a correlation coefficient ( $\mathrm{r}$ ) of 0.51 . The adjusted $\mathrm{R}^{2}$ was also high at 0.66. This implied that about $66 \%$ variations in economic growth could be explained by human capital development during the study period, while the remaining $34 \%$ were due to other variables outside the regression model. The coefficients of government expenditure on education and health were also minimal at 0.07 and 0.05 . For instance, 0.08 implies that a $1 \%$ increase in total government expenditure on education would result in a $0.07 \%$ increase in GDP for Brazil during the study period. The results from the model of South Africa were also not as impressive as those of China, Russia and Brazil.

Although all the variables were positive and significant, at varying levels, for OLS and GMM estimators, the impact of government expenditure on education in terms of economic growth, was very low. Specifically, at 0.04 coefficients, this implies that a $1 \%$ increase in total government expenditure on education would result in a $0.04 \%$ increase in GDP for South Africa. Another disturbing trend was the stagnation in the contribution of GEE to economic growth, judging by the GMM estimate of 0.04 . India recorded the least estimated results in our study. Both GEE and PPST were not statistically significant in influencing economic growth. Although total government expenditure on education significantly improved over the years (GMM $=0.05$ ) in terms of stimulating economic growth, the result at the initial stage was very low. For instance, a coefficient of 0.01 implied that a $1 \%$ increase in total government expenditure on education would result in a $0.01 \%$ increase in GDP for India during the study period. Another disturbing trend was the inability to improve the contributions of PPST to growth, judging by the second lag which was not significant at the GMM and had a 
negative sign. The correlation coefficient ( $\mathrm{r}$ ) was also very low at 0.29 , and the adjusted $\mathrm{R}^{2}$ very low at 0.29 . This implied that about $29 \%$ variations in economic growth could only be explained by human capital development, with the remaining $71 \%$ due to other variables outside the regression model.

In general, the OLS and GMM results suggest that the effect of human capital development on economic growth though significant, was limited in the BRICS countries over the past two decades. A comparative analysis of results for all the countries showed that China, Brazil, and Russia were able to utilise their human capital to enhance economic growth more efficiently than South Africa and India. Specifically, within the bloc, China has made the greatest progress in human capital development. Both Brazil and Russia have also recorded some improvement - especially in the contributions of PPST and ESE to economic growth. After India, South Africa had the second lowest human capital development $(\mathrm{r}=0.45)$ based on the result from this study. This is not surprising, given similar results from previous studies (Awan, 2013; Cleeve, 2008; Ikiara, 2003; Fedderke \& Romm, 2005). Although Fedderke and Romm (2005) reported a direct positive relationship between human capital, economic openness, and infrastructure and economic growth in South Africa, Awan (2013) was not too optimistic.

According to Awan (2013) and Aregbesola (2014), South Africa is the only country that has not had noticeable improvements in human capital development - which might not be unconnected with a drop in life expectancy that has resulted from high Human Immunodeficiency Virus (HIV) prevalence rates during the study period. Export is also on the decline. India has the lowest human capital development compared to the other BRICS members at $r=0.29$. Consequently, Cleeve (2008) maintained that the high level of poverty, unemployment, crime and poor infrastructure in South Africa and India could be traced to the less impressive utilisation of human capital during the study period. However, despite the low level of human capital utilisation in both South Africa and India and the attendant negative impact on economic growth, our study still observed moderate positive improvements over the years - judging by the result of the GMM indicators. This notwithstanding, both India and South Africa still need to keep up the pace with other BRICS members if they are to achieve similar human capital development (Aregbesola, 2014; Anyanwu \& Yameogo, 2015).

\section{Conclusion and Implications of the Study}

Conclusions: This paper investigates the effect of human capital development on economic growth - as well as controlling for country differences - in the BRICS economies from 1990 to 2013. Ordinary Least Square (OLS) and Generalized Method of Moments (GMM) were used as the estimation techniques. We also used oneway ANOVA and Scheffe pairwise comparison tests to understand how human capital development differed between each pair of countries. Findings suggest that the effect of human capital development on economic growth, though significant, was limited in these countries during the study period. Consequently, all the hypotheses were supported at varying levels of significance. Specifically, all the results were significant except the influence of government expenditure on education $(\beta$-Coefficient $=0.01$, $t$-Statistic $=1.32)$ and the proportion of the population registered in primary, secondary and tertiary education $(\beta$-Coefficient $=-1.32, \mathrm{t}-$ Statistic $=-0.13$ ) on economic growth in India. The findings therefore provide overall support for the four human capital dimensions, by confirming strong positive relationships between human capital development and economic growth. In general, the impact of human capital development on economic growth in BRICS countries is limited and sometimes negligible for both GMM and OLS estimators.

For instance, this study observed that a $1 \%$ increase in government expenditure on education would result in a $0.13 \%$ increase in GDP for China, a $0.06 \%$ increase in Russia, a $0.07 \%$ increase in Brazil, a $0.04 \%$ increase in South Africa, and a $1 \%$ increase in GDP in the India. In econometrics, these results imply a minimal or negligible impact of human capital development on economic growth. Alternatively, the low level of coefficients also leads us to confirm the validation of our results against those of Nonnemen and Vanhoudt (1996) - which were used as a proxy for human capital share of total government expenditure on education. In addition, a comparative analysis of results also showed that China, Brazil and Russia were able to utilise their human capital to enhance economic growth more efficiently than South Africa and India. In addition, our analyses show that these countries use and emphasise different human capital management practices. Our study therefore provides possible reasons for China's better use of human capital, and the lessons other 
developing countries could learn from BRICS countries, especially China, Brazil and Russia. Lastly, this study empirically validates an ideal-type human capital development for many developing economies.

Theoretical and Managerial Implications of the Study: This paper contributes to the existing literature in many ways. First, it provides overall support for the four human capital dimensions, by confirming strong positive relationships between human capital development and economic growth. It was an attempt to generalise the efficacy of four human capital dimensions proposed by European Union (investment in education, the use of human capital stock, productivity of human capital and demographics, and also employment of human capital) and the World Economic Forum (Education, Wealth and Wellness, Workforce and Employment, and Enabling Environment). Overall, the paper argues that the classical theory of economic growth, combined with the new theory of economic growth and the theory of market value, will not only help sustain a strategy tripod, but also shed significant light on the most fundamental questions confronting human capital development and economic growth in many developing economies. Second, unlike previous studies which largely consider either developed and developing economies, or a group of both developed and developing economies, our study focuses solely on developing countries (BRICS countries), this paper therefore argues that the practice of pooling developing and developed economies together in analysing the impact of human capital development on economic growth is inappropriate.

This is because developed economies have substantial amounts of two-way human capital flows, when compared to developing nations (Wyk \& Lal, 2008; El-Wassal, 2012). Third, this study empirically validates an ideal-type human capital development for many developing economies. The findings are expected to help developing economies and human capital managers recognise the potential of these four human capital development practices and assist them in designing human capital to achieve the desired growth. In addition, many developing countries are going through globalisation to take advantage of critical resources such as human capital (UNCTAD, 2015; Appleton \& Teal, 1998). These trends pose a unique challenge for many policy-makers and human capital managers (Benhabib \& Spiegel, 1994; Pelinescu, 2015). This study provides a window of opportunity for restructuring human capital development practices. Another policy implication derived from this study is that a country's capacity to improve economic growth will depend on its capacity to formulate policies to promote human capital development. According to UNDP (2014) and De la Fuente and Doménech $(2000,2006)$, policy issues like investment in education, the use of human capital stock, productivity of human capital and demographics and employment of human capital, are all imperatives for improving economic growth.

Based on the findings in this study, there is urgent need for policy-makers in Russia to prioritise government spending on education and health, for the desired growth to be achieved. There is also a need to prioritis e the quality of education and training to improve the contribution of R\&D and P\&I to economic growth, while taking advantage of its wealth of natural resources, skilled labour force and relative political stability (Awan, 2013). There is a need for South African policy-makers to increase government expenditure on education to boost economic growth, and sustain a government drive in building infrastructural facilities, employment provision and crime reduction (Cleeve, 2008; Ikiara, 2003). Lastly, India recorded the least estimated results in our study. Consequently, there is need for the Indian government to increase expenditure on education, and to have a gradual reduction in public debt, and to free resources needed for infrastructural facilities and access to qualitative primary, secondary and tertiary education (Fedderke \& Romm, 200; Awan, 2013). However, care must be taken in using the output of this study, due to some inherent limitations. One of the main methodological problems is the choice of indicator used to measure human capital development. Past studies have used varied measures, which many believed could influence the outcome of their studies.

For instance, Nonnemen and Vanhoudt (1996) used as proxy in the MRW model, the share of education expenditure in GDP, while, Islam (1995) used average number of years of schooling of the population over 25 years as a proxy for human capital (Pelinescu, 2015). However, the use of Murthy and Chien's (1997) weighted average of the population registered in primary, secondary and tertiary education in this study was deliberate. It was based on a gap identified and positioned for future studies by Pelinescu (2015) and Adelakun (2011). The use of cross-sectional data to empirically show which human capital development practices are expected to enhance economic growth could suggest little regarding the process of implementation of human capital development practices or the causal relationship between human capital 
development measures and economic growth. According to Ahmad and Schroeder (2003), two countries may correctly identify which human capital development practices to implement, and yet only one may successfully attain higher economic growth because of dissimilarity in the implementation process. However, a future longitudinal study could focus on the dynamic nature of human capital development practices.

In addition, similar to most empirical literature on the human capital-growth relationships using crosscountry evidence (Anyanwu, 2012; Hailu, 2010), the study suffers from the problems of endogeneity (since most explanatory variables are likely to be jointly endogenous with economic growth). This may lead to biases from simultaneous or reverse causation, since human capital development may cause higher economic growth as opposed to the opposite. There is also the presence of periods and country-specific omitted characteristics or variables affecting both human capital development and economic growth (El-Wassal, 2012). Although the GMM approach was adopted in this paper to address any potential endogeneity, a welldesigned research study using longitudinal or panel data can also address the issue of causality (El-Wassal, 2012; Barro \& Lee, 1993). Lastly, due to data limitation, further studies might consider the inclusion of omitted variables. Chief among the omitted variable are infrastructural facilities, and educational and institutional quality (Anyanwu \& Yameogo, 2015; El-Wassal, 2012; Barro, 1991). Further research is also needed to understand how educational and institutional quality influence the choice of human capital development practices and its effect on economic growth, and the ability to generalise these findings across countries.

\section{References}

Abramowitz, M. (1981). Welfare quandaries and productivity concerns, American Economic Review, 71(7), 117.

Adelakun, O. J. (2011). Human capital development and economic growth in Nigeria, European Journal of Business and Management, 3(9), 29-38.

Agarwal, G. \& Khan, M. A. (2011). Impact of FDI on GDP: A comparative study of China and India, International Journal of Business and Management, 6(10), 71-79.

Ahmad, S. \& Schroeder, R. G. (2003). The impact of human resource management practices on operational performance: Recognizing country and industry differences, Journal of Operations Management, 21(2), 19-43.

Akinlo, A. E. (2004). Foreign direct investment and growth in Nigeria An empirical investigation, Journal of Policy Modeling, 26(3), 627-639.

Anyanwu, J. C. (2011). Determinants of foreign direct investment inflows to Africa, 1980-2007, Working Paper No. 136, African Development Bank, Tunis.

Anyanwu, J. C. (2012). Why does foreign direct investment go where it goes? New evidence from African countries, Annals of Economics and Finance, 13(2), 433-470.

Anyanwu, J. C. \& Yameogo, N. D. (2015). What drives foreign direct investments into West Africa? An Empirical investigation, African Development Review, 27(3), 199-215

Appleton, S. \& Teal, F. (1998). Human capital and economic development. ADB Economic Research paper, $39(4), 1-17$.

Aregbesola, A. R. (2014). Foreign direct investment and institutional adequacy: New Granger causality evidence from African countries, South African Journal of Economic and Management Sciences, 17(5), 557-568.

Asika, N. \& Awolusi, O. D. (2013). Modeling Critical Success Factors of Business Process Re-Engineering and Business Performance of Nigerian Oil and Gas Companies, International Journal of Services and Operations Management, 15(1), 28-43.

Asikhia, U. O. \& Awolusi, O. D. (2015). Assessment of Critical Success Factors of Business Process Reengineering in the Nigerian Oil and Gas Industry, South African Journal of Business Management, $46(2), 1-14$.

Awan, A. G. (2013). Diverging trends of human capital in BRICS countries, International Journal of Asian Social Science, 2(12), 2195-2219.

Awolusi, O. D. (2013a). Effects of motivation on employees' job commitment in the Nigerian banking industry: an empirical analysis, International Journal of Business and Innovation Research, 1(3), 1-17. 
Awolusi, 0. D. (2013b). The effects of total quality management on customer service management in the Nigerian banking industry: an empirical analysis, International Journal of Management and Network Economics, 3(1), 57-77.

Barro, R. (1991). Economic growth in a cross-section of countries, Quarterly Journal of Economics, 106(2), 407-443.

Barro, R. J. \& Lee, J. W. (1993). International comparisons of educational attainment, Journal of Monetary Economics, 32(3), 363-394.

Barro, R. J. \& Sala-i-Martin, X. (1995). Economic growth. New York: McGraw-Hill.

Benhabib, J. \& Spiegel, M. M. (1994). The role of human capital in economic development. Evidence from aggregate cross-country time, Journal of Monetary Economics, 34(3), 143-173.

Bhagwati, J. N. (1978). Anatomy and consequences of exchange control regimes. New York: Balinger Publishing.

Bhagwati, J. N. (1985). Investing abroad: Esmée Fairbairn Lecture. Lancaster: Lancaster University Press.

Bhagwati, J. N. (1994). Free trade: Old and new challenges, Economic Journal, 104(3), 231-246.

Bils, M. \& Klenow, P. J. (2000). Does schooling cause growth? American Economic Review, 90(5), 1160-1183.

Blomstrom, M. \& Kokko, A. (1998). Multinational corporations and spillovers, Journal of Economic Surveys, 12(3), 247-277.

Blomstrom, M., Lipsey, R. E. \& Zejan, M. (1996). Is fixed investment the key to economic growth, Quarterly Journal of Economics, 111(3), 269-276.

Brecher, R. A. \& Findlay, R. (1983). Tariff, foreign capital and national welfare with sector specific factors, Journal of International Economics, 14(3), 277-288.

Bundell, R., Dearden, L., Meghir, C. \& Barbara, S. (1999). Human capital investment: The returns from education and training to the individual, the firm and the economy, Fiscal Studies, 20(1), 1-23.

Canton, E., Minne, A., Nieuwenhuis, B. \& Marc-van der Steeg, S. (2005). Human capital, R \& D and competition in macroeconomic analysis, Working Paper No. 38 ENEPRI /August 2005.

Cleeve, E. (2008). How effective are fiscal incentives to attract FDI to sub-Saharan Africa. The Journal of Developing Areas, 42(1), 135-153.

Coe, D. T. \& Helpman, E. (1995). International R\&D spillovers, European Economic Review, 39(5), 859-887.

De La Fuente, Á. \& Domenéch, A. (2000). Human capital in growth regressions: how much difference does data quality make? Economic Department Working Paper No262, Paris: OECD 35.

De La Fuente, Á. \& Domenéch, A. (2006). Human capital in growth regressions: how much difference does data quality make? Journal of the European Economic Association, 4(1), 1-36.

De Mello, L. R. (1996). Foreign direct investment, international knowledge transfers, endogenous growth: Time series evidence. Department of Economics, University of Kent, 234-240.

De Mello, L. R. (1997). Foreign direct investment in developing countries and growth: A selective survey, Journal of Development Studies, 34(3), 1-34.

De Mello, L. R. (1999). Foreign direct investment-led growth: Evidence from time series and panel data, Oxford Economic Papers, 51(2), 133-151.

Durham, B. (2004). Absorptive capacity and the effects of foreign direct investment and equity foreign portfolio investment on economic growth, European Economic Review, 48(2), 285-306.

Eaton, J. \& Kortum, S. (1999). International technology diffusion: Theory and Measurement, International Economic Review, 40(3), 537-570.

El-Wassal, K. A. (2012). Foreign direct investment and economic growth in Arab Countries (1970-2008): An inquiry into determinants of growth benefits, Journal of Economic Development, 37(4), 79-100.

Fedderke, J. \& Romm, A. T. (2005). Growth impact and determinants of foreign direct investment into South Africa, 1956-2003. Economic Modelling, 23(2), 738-760.

Felipe, J. (1997). Total factor productivity growth in East Asia: A critical survey, Economics and Development Research Center Report Series No. 65, Asian Development Bank, 233-235.

Filmer, D. \& Pritchett, L. H. (2001). Estimating wealth effects without expenditure data or tears: An application to educational enrollments of India, Demography, 38(1), 115-132.

Frenkel, M., Funke, K. \& Stadtmann, G. (2004). A panel analysis of bilateral FDI flows to emerging economies, Economic System, 28(3), 281-300.

Funke, M. \& Strulik, H. (2000). On endogenous growth with physical capital, human capital and product variety, European Economic Review, 44 (2), 491-515.

Goldman Sachs. (2001). Building better global economic BRICs. 
Grammy, A. P. \& Assane, D. (1996). New evidence on the effect of human capital on economic Growth, Applied Economic Letters, 3(3), 121-124.

Grossman, G. M. \& Helpman, E. (1990). Trade, innovation, and growth, The American Economic Review, 80(2), 86-91.

Gustav, R. \& Stewart, F. (2001). Growth and human development; comparative Latin American Experience, Center Discussion Paper, No. 826.

Hailu, Z. A. (2010). Demand side factors affecting the inflow of foreign direct investment to African Countries: Does capital market matter? International Journal of Business and Management, 5(5), 104-116.

Hair, J. F., Anderson, R. E., Tatham, R. L. \& Black, W. C. (1998). Multivariate analysis, 5th ed. Englewood Cliffs, NJ: Prentice-Hall.

Hanushek, E. A. \& Kimko, D. D. (2000). Schooling, labour force quality, and the growth of nations, American Economic Review, 90(5), 1184-1208.

Hanushek, E. A. \& Shultz, G. P. (2012). Education is the key to a healthy economy, The Wall Street Journal, 30 April.

Hanushek, E. A. \& Woessmann, L. (2007). The role of education quality for economic growth, World Bank Policy Research Working Paper, No. 4122, February.

Harbison, F. H. (1962). Human resources development planning in modernizing economies, International Labor Review, 21(3), 453-458.

Horwitz, F. (2005). Human resources and competitiveness, Executive Business Brief, 10(3), 50-52.

Ikiara, M. M. (2003). Foreign Direct Investment (FDI), technology transfer, and poverty alleviation: Africa's hope and dilemma, ATPS Special Paper Series No. 16, Nairobi: African Technology Policy Studies Network, 1-38.

Islam, N. (1995). Growth empirics: A panel data approach, Quarterly Journal of Economics, 110(3), 1127-1170.

Johnson, A. (2006). The Effects of FDI inflows on host country economic growth.

Keller, W. (2001). The geography and channels of diffusion at the world's technology frontier, NBER Working Paper 8150, NBER, MA: Cambridge.

Keller, W. (2002). Trade and the transmission of technology, Journal of Economic Growth, 7(3), 5-21.

Lucas, R. (1988). On the mechanics of economic development, Journal of Monetary Economics, 22(3), 30-42.

Madsen, J. B. (2007). Technology spillover through trade and TFP convergence: 135 years of evidence for the OECD countries, Journal of International Economics, 72(3), 464-480.

Mahe, S. A. (2005). Is globalisation capable of raising living standards, through international trade in Nigeria? Downloaded from http://www.hollerafrica.com/showArticle.php?artId=143\&catId=2 on 21 July 2008.

Mankiw, N. G., Romer, D. \& Weil, D. N. (1992). Contribution to the empirics of economic growth, The Quarterly Journal of Economics, 107(2), 407-437.

Murthy, N. R. \& Chien, I. S. (1997). The empirics of economic growth for OECD countries: Some new findings, Economic Letters, 55(3), 425-429.

Mustapha, A. M., Fakokunde, T. O. \& Awolusi, O. D. (2014). The Quick Service Restaurant Business in Nigeria: Exploring the Emerging Opportunity for Entrepreneurial Development and Growth, Global Journal of Commerce and Management Perspective, 3(3), 8-14.

Ncube, M. (1999). Is human capital important for economic growth in Zimbabwe? African Journal of Economic Policy, 7(3), 1-14.

Nonneman, V. \& Vandhoult, P. (1996). A further augmentation of the Solow model and the empirics of economic growth for OECD countries, Quarterly Journal of Economics, 111(3), 943-953.

Odusola, A. F. (1998). Human investment and the empirics of economic growth, Selected papers for the NES Annual Conference, Ibadan.

OECD. (2010). The high cost of low educational performance. Paris: OECD Publishing.

Ogutcu, M. (2002). Foreign direct investment and regional development: Sharing experiences from Brazil, China, Russia and Turkey. OECD Paper, Paris.

Okojie, C. E. E. (1995). Human capital formation for productivity growth in Nigeria, The Nigerian Economic and Financial Review, 32(3), 44-54.

Ozturk, I. (2007). Foreign direct investment-growth nexus: A review of the recent literature, International Journal of Applied Econometrics and Quantitative Studies, 4(2), 79-98.

Pelinescu, E. (2015). The impact of human capital on economic growth, Procedia Economics and Finance, 22(1), 184-190. 
Pistorius, C. (2004).The competitiveness and innovation, Elektron, 2(3), 234-245.

Riley, G. (2012). Economic growth - the role of human \& social capital, competition \& innovation.

Romer, P. (1986). Increasing returns and long-run growth, Journal of Political Economy, 94(3), 1002-1037.

Romer, P. (1990). Human capital and growth: Theory and evidence, Carnegie Rochester Conference Series on Public Policy, 32(3), 251-286.

RSA. (2013). South Africa's positions in BRICS, Quarterly Bulletin- January to March, 2013. Gauteng Provincial Treasury, Republic of South Africa.

Saggi, K. (2002). Trade, foreign direct investment and international technology transfer: A survey, The World Bank Research Observer, 17(2), 191-235.

Schultz, T. P. (1992). The role of education and human capital on economic development. An Empirical Assessment Center Discussion Paper, Economic Growth Center, Yale University

Serena, M. \& Freire, J. (2001). Human capital accumulation and economic growth, Investigations Economics, 25(3), 585-602.

Siggel, E. (2000). Uganda's policy reforms, competitiveness and regional integration industry: A comparison with Kenya. African Economic Policy, Discussion paper 24. Washington: United States Agency for International Development: Bureau for Africa.

Siggel, E. (2001). India's trade policy reforms and competitiveness industry in the 1980s, World Economy, $322(3), 159-183$.

Temple, J. (1999). A positive effect of human capital on growth, Economics Letters, 65(3), 131-134

UNCTAD. (2013). World investment report: Global value chains: Investment and trade for development. New Geneva: United Nations.

UNCTAD. (2015). World investment report. New York: United Nations.

UNDP. (2014). United Nations Development Programme, Human Development Report

UNESCO. (2005). World report: Towards knowledge societies. New York: UNESCO Publishing.

Wyk, J. V. \& Lal, A. K. (2008). Risk and FDI flows to developing countries, South African Journal of Economic and Management Sciences, 11(4), 511-528.

Young, A. (1991). Learning by doing and the dynamic effects of international trade, The Quarterly Journal of Economics, 106(2), 369-405. 